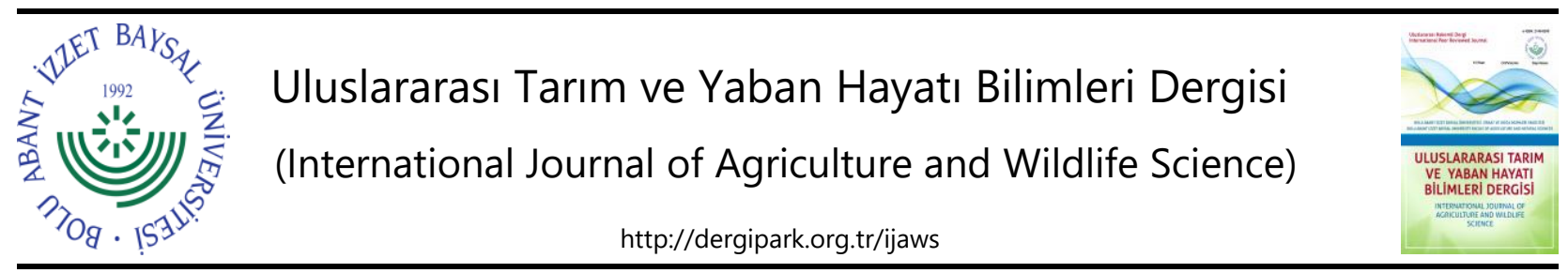

Araştırma Makalesi

\title{
Sanayi İşletmecilerince Algılanan Çevre Sorunları ve Nedenleri (TR83 Bölgesi Araştırması)
}

\author{
Hayati Gönültaş* (D) , Halil Kızılaslan \\ Tokat Gaziosmanpaşa Üniversitesi, Ziraat Fakültesi, Tarım Ekonomisi Bölümü, Tokat \\ Geliş tarihi (Received): 20.04.2021 Kabul tarihi (Accepted): 04.08.2021
}

Anahtar kelimeler:
Çevre sorunları, TR83
Bölgesi ve tarımsal üretim,
sanayi işletmecisi, sanayileşme, farkındalık

\section{*Sorumlu yazar}

hgonultas@hotmail.com.tr
Özet. Bu çalışmada, TR83 Bölgesi'ndeki Tokat, Samsun, Çorum ve Amasya illerindeki sanayi işletmecilerinin çevre sorunlarına yönelik algı ve düşüncelerinin belirlenmesi, farkındalıklarının ölçülmesi ve çevre koruma konusundaki duyarlııklarının artırılması amaçlanmıştır. Bölgedeki sanayi tesisleri ve tarımsal üretimin tarım arazileri, yer altı ve yer üstü suları ve havaya olumsuz etkilerinin araşsırıması amacıyla, bölge illerinden yüzey sularına ve sanayi tesislerine yakınlığı nedeniyle kirlilik etkilerine açık yerler çalışma alanları olarak seçilmiş ve toplam 156 sanayi işletmecisiyle anket yapılmıştır. Sanayi işletmecilerine göre sorunların başında evsel atık ve fosseptik sorunu gelmekte, neden olarak ise çarpık kentleşme görülmektedir. Bu nedenle, su kirliliği ve düzensiz kentleşmeye yol açan etkenler için gerekli tedbirlere başvurulmalıdır. Çevre duyarlıı̆̆ı ve farkındalığı için sanayi işletmecilerine ilgili kuruluşlarca sürekli eğitim verilmelidir.

\section{Environmental Problems Perceived and Causes by Industrial Operators (TR83 Region Survey)}

\section{Keywords: \\ Environmental problems, TR83 Region and agricultural production, industrial operaton, industrialization, awareness}

\begin{abstract}
In this study, it was aimed to determine the perceptions and thoughts of industrial operators in Tokat, Samsun, Çorum and Amasya provinces in the TR83 Region, to measure their awareness and to increase their sensitivity on environmental protection. In order to investigate the negative effects of industrial facilities and agricultural production on agricultural lands, groundwater and surface water and air in the region, places open to pollution effects due to their proximity to surface waters and industrial facilities were selected as working areas and a total of 156 industrial operators were surveyed. According to industrial operators, domestic waste and septic tanks are the main problems, and unplanned urbanization is seen as the cause. For this reason, necessary measures should be taken for the factors that cause water pollution and irregular urbanization. For environmental awareness and awareness, continuous training should be given to industrial operators by relevant organizations.
\end{abstract}




\section{GíRiş}

İnsanların çevreye doğal olmayan bir biçimde etkileri ile oluşan ve toprak, hava, su ve gürültü kirliliği gibi çeşitli şekillerde ortaya konulabilecek düzensizlikler, çevre sorunu olarak adlandırılır. Gerekli tedbirler alınmadığı takdirde çevre sorunlarının tüm dünya ülkelerinin geleceğini tehdit etmesi ise kaçınılmaz olacaktır. İçinde bulunulan yüzyılın en büyük sorunlarından biri, dünyayı ciddi şekilde tehdit eden çevre sorunlarıdır. Bunlar globalleşme etkisiyle uluslararası bir boyuta taşınmış ve küresel çevre sorunları haline gelmiştir (Çağlar, 2017).

Dünya'da var olan çevre kirliliği eko-sistemin dengesini bozmakta ve bunun sonucu olarak küresel ısınma gibi iklim değişikliklerine neden olmaktadır (Kızılaslan ve Kızılaslan, 2009). Aşırı kirlenmeler en çok da çocukları etkilemekte dünyada yılda 1.7 milyon çocuk hayatını kaybetmektedir. Suyun aşırı kirliliği, hava kirliliği en fazla tehdit oluşturan sorunların başında gelmekte, binlerce çocuk hava kirliliği nedeniyle oluşan solunum hastalıklarına yakalanarak yaşamını yitirmektedir. İnsanlar, yeterli temiz su bulunmadığından dolayı ishale ve sivrisinekler sebebiyle sıtma hastalıklarına yakalanmaktadırlar (Anonim, 2017a).

Çevre koruma konusundaki çözüm arayışları daha çok kirliliğin önlenmesi temeline dayanmakta idi. 1980'lerin başında ise "Çevre yönetimi" yaklaşımı benimsenmeye başlanmıştır. İleri ki zamanlarda ise "endüstriyel ekoloji" yaklaşımı gündeme gelmiş ve endüstriyel sistemlerdeki madde ve enerji akışını, akışın çevre üzerindeki etkilerini, teknoloji ve uygulamalarının bu akış üzerindeki etkilerini anlamaya çalışmıştır. Daha sonra ise bunlara toplam kalite yaklaşımı da eklenmiştir. Sonuç olarak ise atık azaltılması, kirlilik önleme, geri dönüştürme, yeniden kullanım, çevreye daha duyarlı ürünlerin tasarımı gibi konulara ilgi ve araştırmalar hızla artmıştır (Yücel ve Ekmekçiler, 2008).

Ekonomik iş birliği ve Kalkınma Örgütü (OECD) ülkelerinden birinde yaşayan bir kişinin yıllık olarak ortaya çıkardığı atık miktarı 2015 yılı itibariyle ortalama 500 kilogramdan fazladır. OECD çevre raporuna göre, bu miktar 2000 yılına göre azalma gösterirken, 1990 yılına göre ise artış göstermektedir. Çöplerin toprağa gömme işleminin kullanılmasında Yeni Zelanda, Şili ve Türkiye ilk üçte yer almaktadır. Çöpü yakarak imha eden Japonya önemli bir enerji kazancı sağlarken, imha ettiği çöplerin bir kısmını ise gübreye dönüştürmektedir. Çöpü enerjiye dönüştüren diğer iki ülke Norveç ve Danimarka'dır. Almanya ise geri dönüşümle en fazla gübre üreten ülkedir (Anonim, 2015a). Karbondioksit $\left(\mathrm{CO}_{2}\right)$, metan $\left(\mathrm{CH}_{4}\right)$ ve diazotmonoksit $\left(\mathrm{N}_{2} \mathrm{O}\right)$ gazları atmosferde birikerek son 800000 yılın en yüksek düzeyine ulaşmıştır (Anonim, 2018a).

Çevre sorunlarının yalnızca yerel bir sorun olmadığı, aksine tüm toplumları etkileyen küresel bir sorun olduğu ortadadır. Geçen zaman içerisinde sorunlar büyüyerek iyice karmaşık bir hal almış ve ülkelerin tek başına üstesinden gelemeyecekleri duruma ulaşmıştır. Çevre sorunları gitgide kirliliğin kaynağı ülkeyle sınırla kalmamakta, dünyadaki tüm ülkeleri etkiler boyuta ulaşmaktadır. Sorunların büyüklüğü ise ulusal ve uluslararası olarak yeniden yapılanma ve iş birliği gerektirmektedir. Sağlıklı yaşam için gerekli olan çevre düzenlemeleri önem kazanmakta, bu düzenlemelerin de yeni örgütlenmeler ve hukuki düzenlemeler şeklinde olması gerekmektedir (Kaypak, 2012).

Hindistan'da Delhi şehri de kirlilik seviyelerindeki ani yükselişe karşı savaşmaya devam etmekte ancak, popüler turistik bir yer olan Varanasi en kirli kent olma yönünde hızla ilerlemektedir. Burada Hava Kirliliği Endeksi (AQI), Merkez Kirlilik Kontrol Kurulu'nun (CPCB) verilerine göre endişe verici bir seviye olan 491 PM seviyesine ulaşmıştır. Hindistan'ın şehirleri Ghaziabad (485), Gurgaon (480), Noida (470), Delhi (468)'de kirlilik seviyesinde en üst düzeylere ulaşmıştır (Anonim, 2017b).

Dura (2012), makalesinde ekonominin kıtlığa karşı savaş olarak yapılan faaliyet olduğunu ancak, üretim ve tüketim olarak gösterilen bu faaliyetin kaliteli çevreyi tüketerek kıt kaynak listesine bir yenisini eklediğini belirtmektedir.

New York'taki çevreci bir örgüt Blacksmith Enstitüsü'nün araştırmalarına göre, yeryüzünde çevre sorunlarının çok yaşandığı yerlerin başında bir dönem kimyasal silah olarak kullanılan sârin ve hardal gazlarının üretildiği Rusya'nın Dzerzhinsk şehri ile Zambiya kasabalarından bakır işletmeciliğinin yaygın olduğu Kabve gelmektedir. Enstitüye göre çevre kirliliği dünyada 1 milyar kişiyi ciddi hastalıklara maruz bırakmaktadır. Kirlilikte en yüksek diğer yerler ise şunlardır; Ukrayna-Çerbonil, Dominik Cumhuriyeti-Haina, Peru-La Oroya, Çin-Linfen-, KırgızistanMailuu Suu, Rusya -Norilsk, Hindistan-Ranipet ve Rusya-Rudnaya Pristan'dır (Anonim, 2006).

2018 Birleşmiş Milletler dünya su geliştirme raporuna göre, hızla artmakta olan dünya nüfusu nedeniyle gelecek 30 yıl içinde global olarak gereksinim duyulan su gereksinimin en az 1/3 oranında artacağı tahmin edilmektedir. Bugün, 2 milyarın üzerinde bir nüfus temiz su kaynaklarına ulaşamamaktadır. Bunun 2050'li yıllarda 3 milyar civarında olacağı tahmin edilmektedir. Dünyadaki atık suların \%80'i arıtılamamakta, yaklaşık 1.8 milyar insan kirli suları tüketmektedir (Anonim, 2018b).

Her yıl, ABD tarımında yetmiş civarı kimyasal madde içeren milyarlarca kilo pestisit kullanılmakta ve tatlı su kaynakları kirletilmektedir. Kimyasallar yer altı suyu kirliliğine de yol açmaktadır. 2014 yılında bir kimyasalın Elk 
Nehri'ne sızmasıyla Batı Virginia'da yoğun bir su kirliliği oluşmuş, bu durum Charleston şehrinde aşağı havzadaki suyun ve başka 9 bölgenin kirlenmesine yol açmıştır (Anonim, 2019a).

Avrupa Birliğine üye ülkelerince oluşturulan, geleceğe yönelik temiz çevre politikaları, doğal çevrenin yok edilmesine yönelik faaliyetlerden kaçınılması ve sanayileşme esnasında çevre koruma duyarlılıklarının öne çıkarılması çabalarını öngörmektedir. Bu amaçlarla birliğin Amsterdam, Lizbon ve Nice gibi antlaşmaları, çevre ile ilgili somut adımların atılması, kaliteli bir çevre düzeninin sağlanması ve çevre harcamalarının birlikçe finanse edilmesi gerekliliğini ortaya koymaktadır (Aydın ve Çamur, 2016).

Sürekli ve etkin bir çevre denetim sistemi için, çevre konusunda iyi bir eğitim, buna yönelik Sivil Toplum Kuruluşlarının (STK) artırılması, yeni şehir planları yapılması, ormanların artırıması, OSB'lerin kurulması, çöplerin kaynağında ayrıştırılması, kaliteli yakıt, egzoz emisyonlarının kontrolü gerekmektedir. Ayrıca kamu kurum ve kuruluşlarının etkin çalıştıııması ve caydırıc ceza öngören yasaların konulması, yerel yönetimlerin daha etkin şekilde izleme yöntemlerini kullanması önem kazanmaktadır (Anonim, 2018c).

Organize Sanayi Bölgeleri 1960'lı yıllardan başlayarak Türkiye'nin bölgesel kalkınma politikasında önemli bir araç durumuna gelmiştir. Türkiye'de bölgesel kalkınma politikası araçları bakımından OSB'lere özel yer verilmiştir (Çetin ve Kara, 2008).

İnsan faaliyetleri nedeni ile çevresel değerlerin zarar görmesi sonucunda ortaya çıkan hava, su ve toprağın zamanla niteliğinin bozularak yaşanırlığını yitirmesi, insan gereksinimleri uğruna aşıı tüketildiği için bitki ve hayvan topluluklarının yok olmaya yüz tutması çevre sorunu olarak adlandırılabilir. Daha çok çevre kirliliği olarak görülen bu durum doğal afetler, yanardağlar, şiddetli yağmur ve seller vb. olaylar sonucu ortaya çıkabilmektedir. Ama çevre sorunları çoğunlukla insan kaynaklıdır (Kaypak, 2010).

Ekonomik büyüme, enerjinin ve diğer girdilerin daha çok kullanılması atıklarda artış meydana getirmekte ve buna dayalı olarak çevre kirliliği de hızla artmaktadır. Kirlilik boyutları ise artarak küresel ısınma gibi büyük sorunlara yol açmaktadır. Bu açıdan Avrupa ülkeleri çevre vergisi veya yeşil vergisi gibi değişik önlemlere başvurmaktadır. Türkiye'de de uygulanan çevre temizlik vergisi buna örnek sayılabilecektir (Fındık, 2007).

Türkiye'de çevresel koruma ve ekonomik açıdan büyüme etkileşimi sırasında ekonomik büyümenin çevreyi dikkat almaksızın yaptığı faaliyetlerle gerçekleştirmek istediği amaçların, doğal ve kaçınılmaz bir sonucu olarak çevre sorunları ortaya çıkmaktadır. Ekonomik yetkinliğini kazanan insanlar sonrasında çevre bilincinin de oluşmasıyla çevrenin korunması gerektiği fikrine sahip çıkılmaya başlanılmakta ancak, bu seferde ekonomik büyüme durağanlaşmaya girmektedir (Sancar, 2007).

Endüstrileşmenin yoğun şekilde yaşandığı Trakya Bölgesinde çevresel duyarlılığa sahip olunarak çevre sorunları açısından gerekli tedbirlerin alınması ve yatırımların buna göre sağlanması gerekmektedir. Aynı zamanda çevre konusunda tüm kurum ve kuruluşların iş birliği içerisinde hareket ederek sorunların çözümüne katkı sağlamaları önem arz etmektedir (Dede, 2010).

"Tarımsal Üreticiler ve Sanayi İşletmecilerinin Çevre Sorunlarına Yönelik Algı ve Düşüncelerinin Belirlenmesi (TR83 Bölgesi Araştırması)" isimli doktora tezimden üretilen bu makalede, yapılan anket çalışmaları ile sanayi işletmecilerinin çevre sorunları ve nedenleri konusundaki algılarının ortaya konulması amaçlanmaktadır.

\section{MATERYAL VE METOT}

TR83 Bölgesinde yapılan bu çalışmada bölgede mevcut olan 4 il Tokat, Samsun, Çorum ve Amasya illerindeki sanayi işletmecileri hedef kitle olarak belirlenmiştir. Çalışmanın ana materyalini, sanayi işletmecileri ile yapılan ankete dayalı yüz yüze görüşmeler sonucu elde edilen birincil veriler ve literatür taramalarından elde edilen ikincil veriler oluşturmaktadır.

Bölgede sanayi işletmecileriyle yapılacak anket sayıları belirlenirken özellikle Organize Sanayi Bölgelerindeki (OSB) işletme sayıları dikkate alınarak örneklem hacmi tespit edilmeye çalışıımıştır. Ayrıca OSB'de olmayan ama büyük tesis olarak kirletici olacağı düşünülen bir işletme de örnekleme dahil edilmiştir

Bölge genelinde tüm sanayi işletmecileriyle anket yapılması imkânı bulunmadığından dolayı ana kütleyi temsil eden yeterli miktarda sanayi işletmecisiyle popülasyona uygun bir örneklem hacmi belirlenmiştir. Araştırmada örneklem hacminin belirlenmesinde \%5 hata payı ve \%95 güven sınır aralığında çalışma yapılmıştır. Sonlu popülasyonlarda standart sapmaya ilişkin bilgiler olmadığında varyans $\left(\sigma^{2}\right)$ da hesaplanamadığından yerine $p$ ve $q$ alınır. İncelenen birimin popülasyondaki oranı olan " $p$ " bilinmediğinden dolayı bu oran 0.5 olarak alınmış ve sanayi işletmecilerinin örnek hacminin belirlenmesinde aşağıdaki formül kullanılmıştır. 


$$
\underline{n=} \frac{N *(p * q)}{(N-1) D^{2}+\left(p^{*} q\right)}
$$

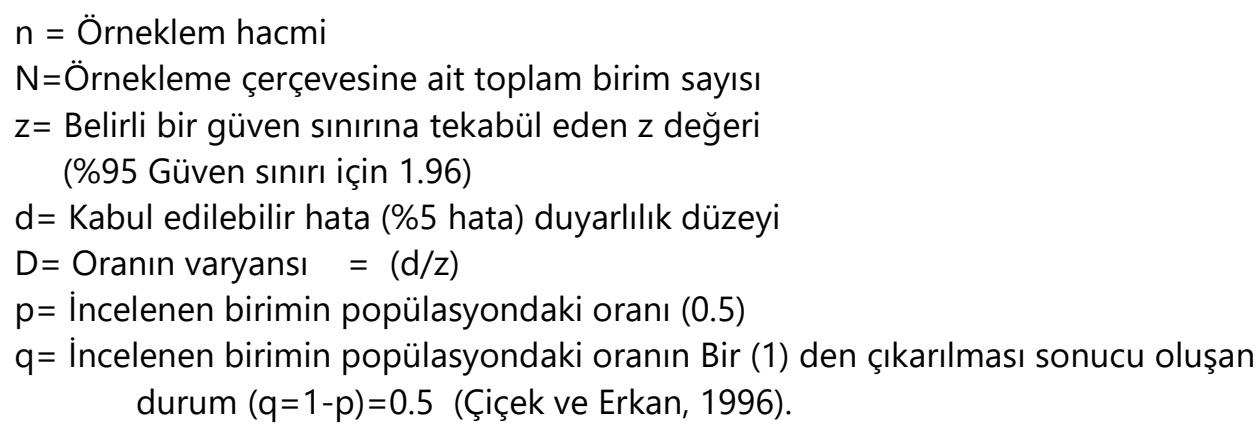

Bu çalışmada yukarıdaki formül uygulanarak araştırmanın ana kütlesini oluşturan işletmelerden Tokat ilinde 46 adet, Samsun ilinde 49 adet, Çorum ilinde 40 adet ve Amasya ilinde 21 adet olmak üzere, bölge genelinde sanayi işletmecileriyle toplam 156 adet anket yapılmıştır.

Sanayi işletmecileri araştırma anketi soruları da 3 bölümden oluşmuştur. Bunlar;

1-Sanayi işletmecilerinin demografik ve sosyal özelliklerini belirlemeye yönelik sorular

2-İsletme profilini belirlemeye yönelik sorular,

3-Çevre sorunlarına yönelik sorulardır.

Çalışmada bölgedeki çevreye ilişkin tutum ve davranışların belirlenmesi için 5'li Likert ölçeğine göre oluşturulan anketlere sanayi işletmecilerince verilen cevaplar değerlendirilmiştir. Buna göre yanıtlar, 1-Kesinlikle katılmıyorum, 2-Katılmıyorum, 3-Fikrim yok, 4-Katılıyorum, 5-Kesinlikle katılıyorum şeklinde olumsuzdan olumluya doğru olup, SPSS istatistik programında elde edilen bilgiler çizelgelerle ortaya konulmaktadır. Ortalamalarda ise 1.00-1.79 kesinlikle katılmıyorum, 1.80-2.59 katılmıyorum, 2.60-3.39 Fikrim yok, 3.40-4.19 katılıyorum ve 4.20-5.00 kesinlikle katılıyorum şeklinde yorumlanmaktadır.

\section{BULGULAR VE TARTIŞMA}

Sanayi işletmelerinin sosyo-ekonomik durumları irdelenecek olursa; TR83 Bölgesinde erkeklerin oranı yaklaşık olarak \%89.1, kadınların oranı ise \%10.9 olarak gerçekleşmiştir. Sanayi işletmelerinde yönetim ve sahiplik açısından kadınların oranı çok düşük seviyelerde olduğundan ankete katılanların sayısı çok az miktardadır. Anket yapılan sanayi işletmecilerinden en yüksek katılım erkeklerde Tokat ilinde \%91.3 oranla görülmekte iken, kadınlarda ise Amasya ilinde \%14.3 oranılla en fazla katılım görülmektedir. Erkeklerde Çorum katılımcıları \%90 ile Tokat'ı izlerken onu Samsun ve Amasya izlemektedir.

Çevreye duyarlı işletmecilik konulu Kahramanmaraş ilindeki araştırmada ankete katılan işletmecilerin \%80.2'si erkeklerden, \%19.8'i ise kadınlardan oluşmuştur (Ceyhan, 2018).

Ankete katılan sanayi işletmesi sahiplerinin bölge genelinde yaş aralığına bakıldığında 26-40 arası \%42.3 ve 41-60 arası \%39.1 olarak belirlenmiştir. Buna göre sanayi işletmecilerinin orta yaş grubunda yoğunlaştığı gözlemlenmiştir. ill bazında ise, en genç yaş olan 18-25 arası grupta \%19 ile Amasya ili öne çıkmakta, Samsun \%14.3 oranıyla onu izlemektedir. Oran olarak yoğun olan grup 26-40 arası yaş arasında ise \%45 ile Çorum öne çıkmakta, Samsun \%44.9 ile onu izlemekte, grupta Tokat \%41.3 olarak yer almakta, Amasya ise grubun en az oranı \%33.3 olarak tanımlanmaktadır. 41-60 arası yaş grubunda Amasya ili \%42.9 ile en yüksek oran olarak görülmektedir.

Çevre sorunları ile ilgili olarak yapılan bir çalışmada çevre sorunlarına gösterilen duyarlılıkta en farklı grubun 56-75 yaş grubu olduğu belirlenmiştir (Tatar, 2021).

Gaziantep'te yapılan bir araştırmada ankete katılan sanayicilerin \%80.9'unun 40 yaşın altında olduğu tespit edilmiştir. Bu durum ise araştırmaya katılan işletmelerdeki yöneticilerin genel olarak genç olduğunu göstermektedir (Özocaklı, 2009).

Medeni durumuna bakıldığında, evlilik oranın \%62.5 gibi yüksek bir oranla Çorum ilinin öne çıktığı, onu \%61.9 ile Amasya'nın takip ettiği, Tokat ve Samsun'un \%50 ile \%49 oranla peşlerinden geldikleri görülmektedir. Dul veya ayrılmış olan kısımda da Çorum \%25 ile başı çekmekte, onu \%17.4 ile Tokat izlemektedir. Bölge genelinde evlilik oranları \%54.5 civarında seyrederken, ileri yaş ortalamasına rağmen bekâr kesim \%26.9 oranındadır. 
Sanayi işletmecilerinin eğitim seviyesinin oldukça iyi olduğu, yükseköğretimin kayda değer ölçüde olduğu söylenebilir. Bölgede yüksekokul seviyesinde \%39.7 oranında en yüksek ortalama göze çarpmaktadır. Bu eğitim seviyesinde Tokat \%45.7 oranıyla başı çekmekte iken, Samsun \%44.9 ile onu izlemekte, Amasya biraz düşük seviyede \%38.1 oranıyla gözükmekte ve Çorum ise en düşük oranda \%27.5 ile yüksekokul eğitim seviyesine sahip bulunmaktadır.

Gaziantep'te yapılan çalışmada araştırmaya katılanların 45.6'sının lisans, \%20.6'sı ön lisans ve \%19.1'inin ortaöğretim mezunu olduğu tespit edilmiştir (Özocaklı, 2009).

Sanayi işletmesinde hane halkı genişlikleri ve işletmede aile mensuplarından çalışanlara ait bilgilere göre, işletme sahiplerinin bölge genelindeki ortalama hane halkı sayıları erkeklerde 2.3 kadınlarda ise 1.4 kişiyi geçmemektedir. Aileden işletmede çalışan sayısı ise küçük işletmelerden bazıları hariç olma üzere işletme sahipleri dışında çalışan neredeyse bulunmamaktadır.

İşletmecilerin çağın gerektirdiği tüm iletişim kanallarını kullandığı, bölgede internet kullanma oranlarının \%89.7'lerde olduğu, özellikle birçok büyük firmanın kendi Web sitesini kurduğu ve birçoğunun bu site üzerinden iletişim kurduğu belirlenmiştir.

Bölgedeki işletmeler genellikle limited şirket olarak yapılandırımışlardır. Samsun ilinde \%40.8 oranında anonim şirket bulunmakta, limited şirket ise ondan biraz daha fazla olarak \%51.0 oranında gözükmektedir. Tokat ise \%58.7 oranında limited şirket bulunmakta, Çorum ilinde ise limited şirket oranı $\% 40.0$ ve anonim şirket oranı \%35.0'dir. Amasya ilinde \%81.0 oranında limited şirket bulunmaktadır. Bölge genelinde ise limited şirket \%54.5 oranındadır. Bunların ortakları ise çoğunlukla aile fertlerinden oluşmaktadır. Çalışmada köklü ve geleneksel işletmeler bulunmakta, ancak bununla birlikte daha çok 10-15 yıllık deneyime sahip işletmecilerle görüşülmüştür.

Kahramanmaraş'taki çalışmada ankete katılan firmaların 40 tanesinin 1 ila 9 yıl arasında, 41 tanesinin 10 ila 19 yıl arasında, 17'sinin 20 ila 29 yıl arasında ve 23 tanesinin ise 30 yıl üzeri faaliyet gösterdikleri belirlenmiştir (Ceyhan, 2018).

Bölgedeki illerde öne çıkan sanayi işletmelerinde üretilen ürün grupları ve pazarlama anlamında yurt içi ve yurt dışı satışlarına göre Tokat'ta gıda ve tekstil tarzı işletmeler öne çıkarken, Samsun'da gübre, kâğıt ve bazı kimyasal üreten işletmeler olmakla birlikte gıda üretimi öne çıkmaktadır. Çorum'da makine üretim işletmeleri çoğunlukta iken, Amasya'da mermer ve maden işletmeleri öne çıkmaktadır.

Sanayi işletmelerinin tipi Tokat bölgesinde ağırlıklı olarak aile geçimi ve geliri artırma amaçlı ticari işletmeler şeklinde iken Samsun ilinde ise yüksek gelir elde etme amaçlı sanayi işletmeleri öne çıkmaktadır. Çorum ve Amasya ilinde aile geçimi ve geliri artırma amaçı ticari işletmeler ve yüksek gelir elde etme amaçlı sanayi işletmeleri birbirlerine yakın olsa da sanayi işletmeleri biraz daha fazla gözükmektedir. Bölgede de sanayi işletmeleri \%39.1 oranla ve ticari işletmeler \%43.6 oranlardadır.

Gaziantep'te yapılan çalışmada araştırmaya katılan işletmelerin \%38.2'ini plastik sektörü, \%14.7'sini tekstil sektörü, \%13.2'sini ambalaj sektörü ve \%11.8'ini ise halıcılık sektörü oluşturmuştur. Buna göre işletmelerin \%64.7 oranla tekstil ve plastik sektöründe faaliyet göstermektedir (Özocaklı, 2009).

Atık sorunlarının 1. öncelikli olduğu iller ise 21 adet olup (\%26) bunların bazıları; Ağrı, Bilecik, Bolu, Diyarbakır, Düzce, İzmir, Sinop ve Tokat'tır. 2. öncelikli çevre sorunu olduğu il 20 adettir ve (Illerin \%25'i) Aksaray, Artvin, İstanbul, Rize, Mardin, Muğla ve Van bunlardan bir kaçıdır. 3. öncelikli çevresel sorun olan iller ise 29 adet olup, \%36'ya tekabül etmektedir. Bunlardan bazıları Adıyaman, Ankara, Amasya, Samsun, Sivas, Tekirdağ, Edirne ve Erzurum'dur. Gürültü kirliliği, illerin \%3.7'sinde birinci öncelikli sorun olup, bu iller Antalya, Adana ve Eskişehir iken, ikincil önemde görülen sorun olduğu iller, Tunceli ve Sivas (illerin \%2'si)'dır. IIllerin \%6'sına tekabül eden Çorum, Iğdır, Kahramanmaraş, Karaman ve Sakarya'da ise sorun üçüncü önceliktedir. Erozyon, Türkiye'nin genel sorunu olmakla beraber 2016 yılında Sivas ilinde ilk sırada iken, Kırşehir'de 4.sırada önemli olarak görülmektedir. Toprak kirliliği ise fazla belirgin olamamakla birlikte, Burdur, Çankırı, Şanlıurfa, Karaman, Denizli, Diyarbakır, Mersin, Kırklareli, Batman, Çorum ve Samsun illerinde öne çıkmaktadır (Anonim, 2018d).

Nijerya'daki bir çalışmada çevre sorunlarının insan sağlığı ve tarımsal üretkenliği etkilediği ortaya konulmuştur. Kirlilik sebebiyle yaşam koşulları zorlaşmaktadır. Su yollarının, yer altı sularının ve toprağın kirlenmesiyle artan toprak kısırığı ile toprak mikro organizmaları yok olarak tarımsal verimlilik azaltmaktadır (ibeji ve Chikaire 2016).

Şekil 1'de Türkiye'de 2016 yıında çevre sorunlarının birinci öncelikli olduğu il sayısı ve oranları yer almaktadır. Buna göre, en büyük sorunun su kirliliği olduğu gözükmekte onu hava kirliliği takip etmektedir (Anonim, 2018d). 


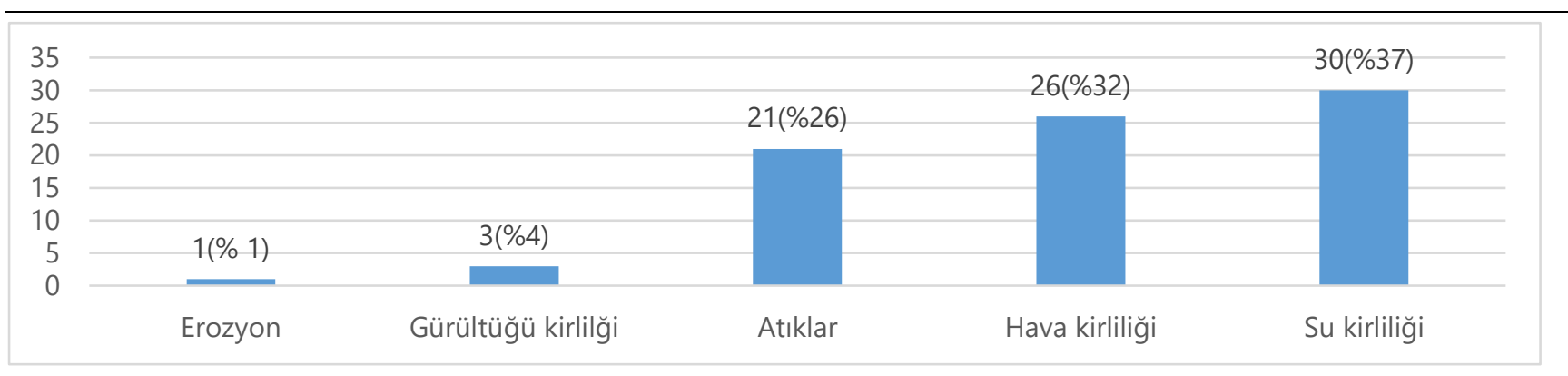

Şekil 1. Türkiye'deki çevre sorunlarında birinci öncelikli il sayıları ve oranları.

Figure 1. The first priority yl numbers and rates of environmental problems in Turkey.

Aşırı ve hızlı tüketim eğilimi insanoğlu için en önemli ve hayati kaynaklar arasında yer alan ve yerine konulması nerdeyse imkânsız olan hava, toprak ve temiz su gibi kaynakların biyoçeşitlilikle beraber kirletilmesi ile neticelenmektedir (Clark, 2007)

Bölgede yaşanan çevre sorunlarına ilişkin sanayi işletmecilerinin algılarının belirlenmesi için yapılan anketler $5^{\prime}$ li Likert ölçeğine göre değerlendirilmiştir. Sorulara verilen yanıtların puanlaması 1-Kesinlikle katılmıyorum, 2Katılmıyorum, 3-Fikrim yok, 4-Katılıyorum, 5-Kesinlikle katılıyorum şeklinde yapılmıştır. Ortalamalarda ise 1.001.79 kesinlikle katılmıyorum, 1.80-2.59 katılmıyorum, 2.60-3.39 Fikrim yok, 3.40-4.19 katılıyorum ve 4.20-5.00 kesinlikle katılıyorum şeklinde yorumlanmaktadır.

Çalışmada sanayi işletmecilerinin bölgeye yönelik olarak çevresel algıları çerçevesinde çevre sorunları ve çevre sorunlarının nedenleri incelenmiştir. Ancak, doktora tezinden üretilen bu makalede, çevre sorunu ve nedeni olarak algılanan en fazla öne çıkanlar yansıtılmıştır. Sanayi işletmecilerinin bölgede en büyük çevre sorunu olarak algıladıkları durumların başında evsel atık ve fosseptik sorunu ile çöp-katı atık kirliliği gelmektedir. Hava kirliliği sorunu da önemli bir sorun algısındadır. Toprak kirliliği ve yer üstü su kirliliği Tokat ili dışında pek de önemsenmemektedir. Amasya ilinde en büyük çevre sorunu olarak görülen evsel atık ve fosseptik sorunu olup, bunu sırasıyla Çorum, Samsun ve Tokat izlemektedir.

Atık maddelerin doğaya bırakılması, hayvan ve bitki türlerinin büyüme ve üreme durumlarını olumsuz etkilemektedir. Kirleticiler, biyoçeşitliliği azaltarak ekosistem yapısına zarar vermektedir. Zehirli atıklar, besin zincirleri yoluyla insan sağlığına da zarar vermektedir (Coşkun, 2019).

Sanayi işletmecilerine göre bölge genelindeki çevre sorunları ile ilgili sorulara verilen cevaplar Çizelge 1'de gösterilmektedir. Buna göre kesinlikle katılıyorum cevabı verenlerin oranının \%76.3 ile en fazla olduğu evsel atık ve fosseptik en büyük sorun olarak görülmektedir. Likert ölçeğine göre de en yüksek ortalama evsel atık ve fosseptik sorunundadır (4.26).

Çizelge 1. TR83 Bölgesinde sanayi işletmecilerine göre çevre sorunları.

Table 1. Environmental problems according to industrial operators in TR83 Region.

\begin{tabular}{|c|c|c|c|c|c|c|c|c|c|c|c|c|}
\hline \multirow{3}{*}{$\begin{array}{c}\begin{array}{c}\text { Çevre } \\
\text { sorunları }\end{array} \\
\text { Hava kirliliği }\end{array}$} & \multicolumn{2}{|c|}{$\begin{array}{c}\text { Kesinlikle } \\
\text { Katılmıyorum }\end{array}$} & \multicolumn{2}{|c|}{ Katılmıyorum } & \multicolumn{2}{|c|}{ Fikrim yok } & \multicolumn{2}{|c|}{ Katılıyorum } & \multicolumn{2}{|c|}{$\begin{array}{c}\text { Kesinlikle } \\
\text { katılıyorum }\end{array}$} & \multirow{2}{*}{$\begin{array}{l}\begin{array}{c}\text { Anket } \\
\text { sayısı }\end{array} \\
\text { Toplam } \\
\end{array}$} & \multirow{3}{*}{$\begin{array}{c}\begin{array}{c}\text { Likert } \\
\text { ölçeği }\end{array} \\
\text { Ortalama } \\
3.56\end{array}$} \\
\hline & Sayı & Oran & Sayı & Oran & Say & Oran & Sayı & Oran & Sayı & Oran & & \\
\hline & 42 & 26.9 & 12 & 7.7 & 3 & 1.9 & 6 & 3.8 & 93 & 59.6 & 156 & \\
\hline $\begin{array}{c}\text { Çöp- katı atık } \\
\text { kirliliği }\end{array}$ & 24 & 15.4 & 14 & 9.0 & & - & 5 & 3.2 & 113 & 72.4 & 156 & 4.12 \\
\hline $\begin{array}{l}\text { Evsel atık ve } \\
\text { fosseptik }\end{array}$ & 25 & 16.0 & 10 & 6.4 & & - & 2 & 1.3 & 119 & 76.3 & 156 & 4.26 \\
\hline
\end{tabular}

Çevre sorunları arasında en tehlikelilerden birisi de zehirli maddeler yoluyla doğanın kirletilmesidir. Birçok kirletici mevcut iken, kirletici listesine her yıl yenileri katılmaktadır. Bu sebeplerle yaşanan birçok felaket insanları ve doğayı etkilemeyi sürdürmektedir (Görmez, 2015).

Tokat ili sanayi işletmecilerinin çevre sorunlarına yönelik algısı incelendiğinde Çizelge 2'de de belirtildiği gibi hava kirliliği ve su kirliliği sorunu (Nehir, dere vb.) önde gelen sorunlar olarak görülmektedir. T.C. Çevre ve Şehircilik Bakanlığı́nın 2018 yııında 2016 yılı verileriyle yayımladığı Türkiye Çevre Sorunları ve Öncelikleri Değerlendirme Raporu'na göre ilde 2. öncelikli sorun olarak gösterilen hava kirliliği ile öncelikli sorun olarak belirtilen su kirliliği yüksek seviyede algılanmaktadır. Oransal olarak karşılaştııılığında \%56.5 kesinlikle katııyorum cevabıyla hava kirliliği sorunu en başta gelmektedir. Likert ölçeğine göre ise en yüksek ortalamalar hava kirliliği ve su kirliliği 
(Nehir, dere vb.) sorununda gözükmektedir (3.39). Evsel atık ve fosseptik sorunu ise diğer illerin aksine pek de önemsenmemektedir.

Çizelge 2 Tokat ilinde sanayi işletmecilerine göre çevre sorunları.

Table 2. Environmental problems according to industrial operators in Tokat province.

\begin{tabular}{|c|c|c|c|c|c|c|c|c|c|c|c|c|}
\hline \multirow{3}{*}{$\begin{array}{c}\begin{array}{c}\text { Çevre } \\
\text { sorunları }\end{array} \\
\\
\begin{array}{c}\text { Su kirliliği } \\
\text { (Nehir, dere } \\
\text { vb.) }\end{array}\end{array}$} & \multirow{2}{*}{\multicolumn{2}{|c|}{$\begin{array}{c}\begin{array}{c}\text { Kesinlikle } \\
\text { Katılmıyorum }\end{array} \\
\text { Sayı / Oran } \\
\end{array}$}} & \multirow{2}{*}{\multicolumn{2}{|c|}{$\begin{array}{c}\text { Katılmıyorum } \\
\text { Sayı/ Oran } \\
\end{array}$}} & \multirow{2}{*}{\multicolumn{2}{|c|}{$\begin{array}{l}\text { Fikrim yok } \\
\text { Sayı/ Oran }\end{array}$}} & \multirow{2}{*}{\multicolumn{2}{|c|}{$\begin{array}{c}\text { Katılıyorum } \\
\text { Sayı/ Oran }\end{array}$}} & \multirow{2}{*}{\multicolumn{2}{|c|}{$\begin{array}{c}\begin{array}{c}\text { Kesinlikle } \\
\text { katılıyorum }\end{array} \\
\text { Sayı / Oran } \\
\end{array}$}} & \multirow{3}{*}{$\begin{array}{c}\begin{array}{c}\text { Anket } \\
\text { sayısı }\end{array} \\
\text { Toplam } \\
46\end{array}$} & \multirow{3}{*}{$\begin{array}{c}\begin{array}{c}\text { Likert } \\
\text { ölçeği }\end{array} \\
\text { Ortalama } \\
3.39\end{array}$} \\
\hline & & & & & & & & & & & & \\
\hline & 14 & 30.4 & 4 & 8.7 & 2 & 4.3 & 2 & 4.3 & 24 & 52.2 & & \\
\hline Hava kirliliği & 17 & 37.0 & 1 & 2.2 & 1 & 2.2 & 1 & 2.2 & 26 & 56.5 & 46 & 3.39 \\
\hline $\begin{array}{l}\text { Evsel atık ve } \\
\text { fosseptik }\end{array}$ & 20 & 43.5 & 7 & 15.2 & & - & 2 & 4.3 & 17 & 37.0 & 46 & 2.76 \\
\hline
\end{tabular}

Tokat'a komşu ve benzerlikleri oldukça fazla olan Sivas'ta da kentleşme ve sanayileşmenin sebep olduğu hava, su, toprak, gürültü ve görüntü kirliliği gibi çevre sorunları oluşmakta, ilin içinden geçen Kızılırmak nehri şehirdeki sanayi tesisleri nedeniyle kirlenmektedir. Özellikle vahşi çöp depolama alanından sızan kirli sular ırmağa karışarak tarımsal üretim topraklarını kirletmektedir (Ergün, 2008).

Samsun ili sanayi işletmecilerinin çevre sorunlarına yönelik algısı incelendiğinde Çizelge 3 'de de görüldüğü gibi çöp-katı atık kirliliği ile evsel atık ve fosseptik sorunu önde gelmektedir. Bu durum T.C. Çevre ve Şehircilik Bakanlığı'nın 2018 yılında 2016 yılı verileriyle yayımladığı Türkiye Çevre Sorunları ve Öncelikleri Değerlendirme Raporu'na göre atıkların 3. öncelikli sorun olduğu iller içerisinde olan evsel atıklar ve fosseptik sorunu noktasında sanayi işletmecilerinin algısının öne geçtiğini göstermektedir. Hava kirliliği sorunu ise raporda bahsedildiği gibi ilin, hava kirliliği sorununun 2. öncelikli sorun olmasıyla örtüşmektedir. Oransal bakıldığında kesinlikle katılıyorum cevabıyla ve \%91.8 oranla çöp- katı atık kirliliği sorunu (Likert'e göre 4.73) ile evsel atık ve fosseptik sorunu başta gelmektedir.

Çizelge 3. Samsun ilinde sanayi işletmecilerine göre çevre sorunları.

Table 3. Environmental problems according to industrial operators in Samsun province.

\begin{tabular}{|c|c|c|c|c|c|c|c|c|c|c|c|c|}
\hline \multirow{3}{*}{$\begin{array}{c}\begin{array}{c}\text { Çevre } \\
\text { sorunları }\end{array} \\
\text { Hava kirliliği }\end{array}$} & \multirow{2}{*}{\multicolumn{2}{|c|}{$\begin{array}{c}\begin{array}{c}\text { Kesinlikle } \\
\text { Katılmıyorum }\end{array} \\
\text { Sayı / Oran }\end{array}$}} & \multirow{2}{*}{\multicolumn{2}{|c|}{$\begin{array}{c}\text { Katılmıyorum } \\
\text { Sayı/ Oran } \\
\end{array}$}} & \multirow{2}{*}{\multicolumn{2}{|c|}{$\begin{array}{l}\text { Fikrim yok } \\
\text { Sayı/ Oran }\end{array}$}} & \multirow{2}{*}{\multicolumn{2}{|c|}{$\begin{array}{c}\text { Katılıyorum } \\
\text { Sayı/ Oran }\end{array}$}} & \multicolumn{2}{|c|}{$\begin{array}{c}\begin{array}{c}\text { Kesinlikle } \\
\text { katılıyorum }\end{array} \\
\end{array}$} & \multirow{3}{*}{$\begin{array}{c}\begin{array}{c}\text { Anket } \\
\text { sayısı }\end{array} \\
\text { Toplam } \\
49\end{array}$} & \multirow{3}{*}{$\begin{array}{c}\begin{array}{c}\text { Likert } \\
\text { ölçeği }\end{array} \\
\text { Ortalama } \\
3.90\end{array}$} \\
\hline & & & & & & & & & Sayı & Oran & & \\
\hline & 9 & 18.4 & 4 & 8.2 & 2 & 4.1 & 2 & 4.1 & 32 & 65.3 & & \\
\hline $\begin{array}{c}\text { Çöp- katı atık } \\
\text { kirliliăgi }\end{array}$ & 3 & 6.1 & & - & & - & 1 & 2.0 & 45 & 91.8 & 49 & 4.73 \\
\hline $\begin{array}{l}\text { Evsel atık ve } \\
\text { fosseptik }\end{array}$ & 4 & 8.2 & & - & & - & & - & 45 & 91.8 & 49 & 4.67 \\
\hline
\end{tabular}

Çorum ili sanayi işletmecilerinin çevre sorunlarına yönelik algısı incelendiğinde Çizelge 4'de de belirtildiği gibi evsel atık ve fosseptik sorunu ile çöp-katı atık kirliliği önde gelen sorunlar olarak görülmektedir. Hava kirliliği sorunu ise sanayi işletmecileri açısından kararsızlık noktasında olmasına karşın T.C. Çevre ve Şehircilik Bakanlığı́nın yayımladığı Türkiye Çevre Sorunları ve Öncelikleri Değerlendirme Raporu'nda belirtilen, ilin hava kirliliğinin 1. öncelikli sorun olduğu iller arasında olmasıyla da kısmen örtüşmektedir. Oransal olarak karşılaştırıldığında ise kesinlikle katılıyorum cevabıyla ve \%92.5 oranla evsel atık ve fosseptik sorunu başta gelmektedir.

Çizelge 4. Çorum ilinde sanayi işletmecilerine göre çevre sorunları.

Table 4. Environmental problems according to industrial operators in Çorum province.

\begin{tabular}{|c|c|c|c|c|c|c|c|c|c|c|c|}
\hline \multirow{3}{*}{$\begin{array}{c}\begin{array}{c}\text { Çevre } \\
\text { sorunları }\end{array} \\
\text { Hava kirliliği }\end{array}$} & \multirow{2}{*}{\multicolumn{2}{|c|}{$\begin{array}{c}\begin{array}{c}\text { Kesinlikle } \\
\text { Katılmıyorum }\end{array} \\
\text { Sayı / Oran } \\
\end{array}$}} & \multicolumn{2}{|c|}{ Katılmıyorum } & \multirow{3}{*}{$\begin{array}{c}\text { Fikrim yok } \\
\text { Sayı/ Oran } \\
-\end{array}$} & \multirow{2}{*}{\multicolumn{2}{|c|}{$\begin{array}{c}\text { Katılıyorum } \\
\text { Sayı/ Oran } \\
\end{array}$}} & \multirow{2}{*}{\multicolumn{2}{|c|}{$\begin{array}{c}\begin{array}{c}\text { Kesinlikle } \\
\text { katılıyorum }\end{array} \\
\text { Sayı / Oran } \\
\end{array}$}} & \multirow{3}{*}{$\begin{array}{c}\begin{array}{c}\text { Anket } \\
\text { sayısı }\end{array} \\
\text { Toplam } \\
40\end{array}$} & \multirow{3}{*}{$\begin{array}{c}\begin{array}{c}\text { Likert } \\
\text { ölçeği }\end{array} \\
\text { Ortalama } \\
3.75\end{array}$} \\
\hline & & & \multicolumn{2}{|c|}{ Sayı/ Oran } & & & & & & & \\
\hline & 9 & 22.5 & 4 & 10.0 & & 2 & 5.0 & 25 & 62.5 & & \\
\hline Çöp- katı atık & 2 & 5.0 & 3 & 7.5 & - & 1 & 2.5 & 34 & 85.0 & 40 & 4.55 \\
\hline Evsel atık ve & 1 & 2.5 & 2 & 5.0 & - & & - & 37 & 92.5 & 40 & 4.75 \\
\hline
\end{tabular}


Likert ölçeğine göre ise en yüksek ortalama evsel atık ve fosseptik sorununda gözükmektedir (4.75). Amasya ili sanayi işletmecilerinin çevre sorunlarına yönelik algısı incelendiğinde Çizelge 5 'de de belirtildiği gibi evsel atık ve fosseptik sorunu ile çöp-katı atık kirliliği önde gelen sorunlar olarak görülmektedir. T.C. Çevre ve Şehircilik Bakanlığı'nın 2018 yılında 2016 yılı verileriyle yayımladığı Türkiye Çevre Sorunları ve Öncelikleri Değerlendirme Raporu'na göre atıklar 3. öncelikli sorun olduğu iller arasındadır ve bu sanayi işletmecilerince algılanan sorunların başında gelmektedir. Rapora göre ilde hava kirliliği 2. öncelikli sorun iken sanayi işletmecileri açısından az da olsa önemli görülmektedir. Oransal olarak karşılaştııldığında ise kesinlikle katılıyorum cevabıyla ve \%95.2 oranla evsel atık ve fosseptik sorunu başta gelmekte, Likert ölçeğine göre de en yüksek ortalama evsel atık ve fosseptik sorununda gözükmektedir (4.86).

Çizelge 5. Amasya ilinde sanayi işletmecilerine göre çevre sorunları.

Table 5. Environmental problems according to industrial operators in Amasya province.

\begin{tabular}{|c|c|c|c|c|c|c|c|c|c|c|}
\hline \multirow{3}{*}{$\begin{array}{c}\begin{array}{c}\text { Çevre } \\
\text { sorunları }\end{array} \\
\text { Hava kirliliği }\end{array}$} & \multirow{2}{*}{$\begin{array}{c}\begin{array}{c}\text { Kesinlikle } \\
\text { Katılmıyorum }\end{array} \\
\text { Sayı / Oran } \\
\end{array}$} & \multicolumn{2}{|c|}{ Katılmıyorum } & \multirow{3}{*}{$\begin{array}{l}\text { Fikrim yok } \\
\text { Sayı/ Oran } \\
\end{array}$} & \multirow{2}{*}{\multicolumn{2}{|c|}{$\begin{array}{c}\text { Katılıyorum } \\
\text { Sayı/ Oran } \\
\end{array}$}} & \multicolumn{2}{|c|}{$\begin{array}{c}\text { Kesinlikle } \\
\text { katılıyorum }\end{array}$} & \multirow{2}{*}{$\begin{array}{c}\begin{array}{c}\text { Anket } \\
\text { sayısı }\end{array} \\
\text { Toplam } \\
\end{array}$} & \multirow{3}{*}{$\begin{array}{c}\begin{array}{c}\text { Likert } \\
\text { ölçeği }\end{array} \\
\text { Ortalama } \\
3.19\end{array}$} \\
\hline & & Say & Oran & & & & Sayı & Oran & & \\
\hline & $\begin{array}{ll}7 & 33.3\end{array}$ & 3 & 14.3 & & 1 & 4.8 & 10 & 47.6 & 21 & \\
\hline $\begin{array}{c}\text { Çöp- katı atık } \\
\text { kirliliği }\end{array}$ & 9.5 & 2 & 9.5 & - & 1 & 4.8 & 16 & 76.2 & 21 & 4.29 \\
\hline $\begin{array}{l}\text { Evsel atık ve } \\
\text { fosseptik }\end{array}$ & - & 1 & 4.8 & - & & - & 20 & 95.2 & 21 & 4.86 \\
\hline
\end{tabular}

Sanayi işletmecilerinin bölgede en büyük çevre sorunu nedeni olarak algıladıkları durumların başında çarpık kentleşme gelirken, arıtma tesislerinin bulunmaması onu takip etmektedir. Nüfus artışı ve çöp-katı atık tesis yetersizliği az da olsa önemsenmektedir.

Tehlikeli ve zehirli maddeler arasında yer alan ağır metaller (kurşun ve cıva vb.), organik klorlu bileşikler (DDT vb.) ve bazı petrol ürünleri hava, kara ve suya bulaşabilir. Ancak asıl tehlikelisi bunların uzun kalış süreleri gösterdiği toprak ve deniz suyudur. Atmosferle taşınan kirleticilerin çökelme veya difüzyonla yüzey sularına aktarılması da mümkün bulunmaktadır (Alsmadi, 2007).

Tüketicilerin son yıllarda özellikle küresel ısınma olmak üzere tüm çevresel sorunlara yönelik duyarlılıklarında artış söz konusudur. İnsanın yaşamını sürdürülebilmesi için yaşanan olumsuzlukların tersine döndürülmesi gerekmektedir (Aydın ve Tufan, 2018).

Çizelge $6^{\prime}$ da bölge genelinde sanayi işletmecileri tarafından çevre sorunlarının nedenlerine ilişkin sorulan sorulara verilen cevaplara göre kesinlikle katılıyorum cevabı verenlerin oranının en fazla \%79.5 ile çarpık kentleşme iken, likert ölçeğine göre de neden olarak 4.38 ortalamayla en fazla oran çarpık kentleşmededir.

Çizelge 6. TR83 Bölgesinde sanayi işletmecilerine göre çevre sorunlarının nedenleri.

Table 6. Causes of environmental problems according to industrial operators in TR83 Region.

\begin{tabular}{|c|c|c|c|c|c|c|c|c|c|c|c|c|}
\hline \multirow{3}{*}{$\begin{array}{c}\begin{array}{c}\text { Çevre sorunu } \\
\text { nedenleri }\end{array} \\
\text { Çarpık kentleşme }\end{array}$} & \multirow{2}{*}{\multicolumn{2}{|c|}{$\begin{array}{c}\begin{array}{c}\text { Kesinlikle } \\
\text { Katılmıyorum }\end{array} \\
\text { Sayı / Oran } \\
\end{array}$}} & \multicolumn{2}{|c|}{ Katılmıyorum } & \multicolumn{2}{|c|}{ Fikrim yok } & \multicolumn{2}{|c|}{ Katılıyorum } & \multicolumn{2}{|c|}{$\begin{array}{c}\text { Kesinlikle } \\
\text { katılıyorum }\end{array}$} & \multirow{2}{*}{$\begin{array}{c}\begin{array}{c}\text { Anket } \\
\text { sayısı }\end{array} \\
\text { Toplam } \\
\end{array}$} & \multirow{2}{*}{$\begin{array}{c}\begin{array}{c}\text { Likert } \\
\text { ölçeği }\end{array} \\
\text { Ortalama }\end{array}$} \\
\hline & & & Sayı & Oran & Sayı & Oran & Sayı & Oran & Sayı / & / Oran & & \\
\hline & 12 & 7.7 & 11 & 7.1 & 1 & 0.6 & 8 & 5.1 & 124 & 79.5 & 156 & 4.38 \\
\hline Nüfus artışı & 27 & 17.3 & 10 & 6.4 & 1 & 0.6 & 3 & 1.9 & 115 & 73.7 & 156 & 3.85 \\
\hline $\begin{array}{l}\text { Çöp-katı atık tesis } \\
\text { yetersizliăi }\end{array}$ & 33 & 21.2 & 28 & 17.9 & 9 & 5.8 & 11 & 7.1 & 75 & 48.1 & 156 & 3.43 \\
\hline $\begin{array}{l}\text { Arıtma tesislerinin } \\
\text { bulunmaması }\end{array}$ & 19 & 12.2 & 19 & 12.2 & 10 & 6.4 & 13 & 8.3 & 95 & 60.9 & 156 & 3.94 \\
\hline
\end{tabular}

Özellikle sanayi bölgelerinin çokluğu nedeniyle iş olanakları bakımından geniş bir istihdam alanına sahip olan Kocaeli, nüfusu son 10 yılda yüzde 28 artmak suretiyle Türkiye'nin en yoğun nüfuslu şehirleri arasında yer almaktadır. Türkiye İstatistik Kurumuna (TÜiK) göre, kent nüfusu 2008 ile 2018 yılları arasında yüzde 28 artarak 1 milyon 906 bin 391'e ulaşmıştır. III, bu dönemde 199 bin 257 kişilik net göç almıştır. Ilde çalışma çağındaki (1564 yaş) nüfusun toplam nüfus içerisindeki payı yüzde 69.4'ü bulmaktadır. İş olanaklarının çeşitliliği dolayısıyla Anadolu'dan göç alan kentlerden biri olan Kocaeli'nde, nüfusun yüzde 71.2'sini kütüğü başka illerde bulunanlar oluşturmaktadır (Anonim, 2019b).

Tokat ili sanayi işletmecilerinin çevre sorunlarının nedenlerine yönelik algısı incelendiğinde Çizelge 7'ye göre çarpık kentleşme ve nüfus artışı büyük nedenler olarak algılanmaktadır. Arıtma tesislerinin bulunmaması ise 
kararsızlık noktasındadır. Oransal bakıldığında ise \%80.4 kesinlikle katılıyorum cevabıyla nüfus artışı başta gelen neden olurken, likert ölçeğine göre en yüksek ortalama çarpık kentleşme nedeninde gözükmektedir (4.37).

Çizelge 7. Tokat ilinde sanayi işletmecilerine göre çevre sorunlarının nedenleri.

Table 7. Causes of environmental problems according to industrial operators in Tokat province.

\begin{tabular}{|c|c|c|c|c|c|c|c|}
\hline $\begin{array}{l}\text { Çevre sorunu } \\
\text { nedenleri }\end{array}$ & $\begin{array}{c}\text { Kesinlikle } \\
\text { Katılmıyorum }\end{array}$ & Katılmıyorum & Fikrim yok & Katılıyorum & $\begin{array}{c}\text { Kesinlikle } \\
\text { katılıyorum }\end{array}$ & $\begin{array}{l}\text { Anket } \\
\text { sayısı }\end{array}$ & $\begin{array}{l}\text { Likert } \\
\text { ölçeği }\end{array}$ \\
\hline & Sayı / Oran & Sayı/ Oran & Sayı/ Oran & Sayı/ Oran & Sayı / Oran & Toplam & Ortalama \\
\hline Çarpık kentleşme & 24.3 & 613.0 & & 36.5 & 76.1 & 46 & 4.37 \\
\hline Nüfus artışı & 48.7 & $\begin{array}{ll}5 & 10.9\end{array}$ & & & 80.4 & 46 & 4.33 \\
\hline $\begin{array}{l}\text { Arıtma tesislerinin } \\
\text { bulunmaması }\end{array}$ & 48.7 & $\begin{array}{ll}5 & 10.9\end{array}$ & 17.4 & 817.4 & 45.7 & 46 & 3.80 \\
\hline
\end{tabular}

Samsun ili sanayi işletmecilerinin çevre sorunlarının nedenlerine yönelik algısı incelendiğinde Çizelge 8'e göre çarpık kentleşme, nüfus artışı ve arıtma tesislerinin bulunmaması ve çöp-katı atık tesis yetersizliği en büyük nedenler olarak algılanmaktadır. Oransal bakıldığında ise \%91.8 ile ve kesinlikle katılıyorum cevabıyla çarpık kentleşme başta gelen neden olurken, likert ölçeğine göre de en yüksek ortalama çarpık kentleşmededir (4.73).

Çizelge 8. Samsun ilinde sanayi işletmecilerine göre çevre sorunlarının nedenleri.

Table 8. Causes of environmental problems according to industrial operators in Samsun province.

\begin{tabular}{|c|c|c|c|c|c|c|c|c|c|c|c|}
\hline \multirow[t]{2}{*}{$\begin{array}{l}\text { Çevre sorunu } \\
\text { nedenleri }\end{array}$} & $\begin{array}{c}\text { Kesinlikle } \\
\text { Katılmıyorum }\end{array}$ & \multicolumn{2}{|c|}{ Katılmıyorum } & \multicolumn{2}{|c|}{ Fikrim yok } & \multicolumn{2}{|c|}{ Katılıyorum } & \multicolumn{2}{|c|}{$\begin{array}{c}\text { Kesinlikle } \\
\text { katılıyorum }\end{array}$} & \multirow{2}{*}{$\begin{array}{c}\begin{array}{c}\text { Anket } \\
\text { sayısı }\end{array} \\
\text { Toplam }\end{array}$} & \multirow{2}{*}{$\begin{array}{c}\text { Likert } \\
\text { ölçeği }\end{array}$} \\
\hline & Sayı / Oran & Say & / Oran & Sayı & / Oran & Sayı & / Oran & Sayı & / Oran & & \\
\hline Çarpık kentleşme & 24.1 & 1 & 2.0 & 1 & 2.0 & & - & 45 & 91.8 & 49 & 4.73 \\
\hline Nüfus artışı & $9 \quad 18.4$ & & - & & - & & - & 40 & 81.6 & 49 & 4.27 \\
\hline $\begin{array}{l}\text { Çöp-katı atık tesis } \\
\text { yetersizliği }\end{array}$ & $\begin{array}{ll}7 & 14.3\end{array}$ & 8 & 16.3 & & - & 1 & 2.0 & 33 & 67.3 & 49 & 3.92 \\
\hline $\begin{array}{l}\text { Arıtma tesislerinin } \\
\text { bulunmaması }\end{array}$ & $\begin{array}{ll}7 & 14.3\end{array}$ & 5 & 10.2 & 2 & 4.1 & 1 & 2.0 & 34 & 69.4 & 49 & 4.02 \\
\hline
\end{tabular}

Çorum ili sanayi işletmecilerinin çevre sorunlarının nedenlerine yönelik algısı Çizelge 9'a göre nüfus artışı, çarpık kentleşme ve arıtma tesislerinin bulunmaması en büyük nedenler olarak algılanmaktadır. Çöp-katı atık tesis yetersizliği ise kararsızık noktasındadır. Oransal olarak bakıldığında ise \%85 ile ve kesinlikle katılıyorum cevabıyla nüfus artışı başta gelen neden olurken, likert ölçeğine göre de en yüksek ortalama nüfus artışı nedeninde gözükmektedir (4.53).

Çizelge 9. Çorum ilinde sanayi işletmecilerine göre çevre sorunlarının nedenleri.

Table 9. Causes of environmental problems according to industrial operators in Çorum province.

\begin{tabular}{|c|c|c|c|c|c|c|c|c|c|c|c|}
\hline \multirow{3}{*}{$\begin{array}{c}\begin{array}{c}\text { Çevre sorunu } \\
\text { nedenleri }\end{array} \\
\text { Çarpık kentleşme }\end{array}$} & \multirow{2}{*}{\multicolumn{2}{|c|}{$\begin{array}{c}\begin{array}{c}\text { Kesinlikle } \\
\text { Katılmıyorum }\end{array} \\
\text { Sayı / Oran } \\
\end{array}$}} & \multirow{2}{*}{\multicolumn{2}{|c|}{$\begin{array}{c}\text { Katılmıyorum } \\
\text { Sayı/ Oran }\end{array}$}} & \multirow{3}{*}{$\begin{array}{c}\text { Fikrim yok } \\
\text { Sayı/ Oran } \\
-\end{array}$} & \multirow{2}{*}{\multicolumn{2}{|c|}{$\begin{array}{l}\text { Katılıyorum } \\
\text { Sayı/ Oran } \\
\end{array}$}} & \multirow{2}{*}{\multicolumn{2}{|c|}{$\begin{array}{c}\begin{array}{c}\text { Kesinlikle } \\
\text { katılıyorum }\end{array} \\
\text { Sayı / Oran } \\
\end{array}$}} & \multirow{3}{*}{$\begin{array}{c}\begin{array}{c}\text { Anket } \\
\text { sayısı }\end{array} \\
\text { Toplam } \\
40\end{array}$} & \multirow{3}{*}{$\begin{array}{c}\begin{array}{c}\text { Likert } \\
\text { ölçeği }\end{array} \\
\text { Ortalama } \\
4.18\end{array}$} \\
\hline & & & & & & & & & & & \\
\hline & 5 & 12.5 & 3 & 7.5 & & 4 & 10.0 & 28 & 70.0 & & \\
\hline Nüfus artışı & 3 & 7.5 & 2 & 5.0 & - & 1 & 2.5 & 34 & 85.0 & 40 & 4.53 \\
\hline $\begin{array}{l}\text { Çöp-katı atık tesis } \\
\text { yetersizliği }\end{array}$ & 9 & 22.5 & 9 & 22.5 & - & & - & 22 & 55.0 & 40 & 3.43 \\
\hline $\begin{array}{l}\text { Arıtma tesislerinin } \\
\text { bulunmaması }\end{array}$ & 5 & 12.5 & 6 & 15.0 & - & 3 & 7.5 & 26 & 65.0 & 40 & 3.98 \\
\hline
\end{tabular}

Amasya ili sanayi işletmecilerinin çevre sorunlarının nedenlerine yönelik algısı incelendiğinde Çizelge 10'a göre çarpık kentleşme, hayvan atık ve gübrelerinin sulara bırakılması ve arıtma tesislerinin bulunmaması en büyük nedenler olarak algılanmaktadır. Çöp-katı atık tesis yetersizliği ise kararsızlık noktasındadır. Oransal bakıldığında ise \%76.2 ile ve kesinlikle katılıyorum cevabıyla çarpık kentleşme başta gelen neden olurken, likert ölçeğine göre de en yüksek ortalama çarpık kentleşmededir (4.24). 
Çizelge 10. Amasya ilinde sanayi işletmecilerine göre çevre sorunlarının nedenleri.

Table 10. Causes of environmental problems according to industrial operators in Amasya province.

\begin{tabular}{|c|c|c|c|c|c|c|c|c|c|c|c|c|}
\hline \multirow{3}{*}{$\begin{array}{c}\begin{array}{c}\text { Çevre sorunu } \\
\text { nedenleri }\end{array} \\
\text { Çarpık kentleşme }\end{array}$} & \multicolumn{2}{|c|}{$\begin{array}{c}\text { Kesinlikle } \\
\text { Katılmıyorum }\end{array}$} & \multicolumn{2}{|c|}{ Katılmıyorum } & \multicolumn{2}{|c|}{ Fikrim yok } & \multicolumn{2}{|c|}{ Katılıyorum } & \multicolumn{2}{|c|}{$\begin{array}{c}\text { Kesinlikle } \\
\text { katılıyorum }\end{array}$} & \multirow{2}{*}{\begin{tabular}{|l|}
$\begin{array}{l}\text { Anket } \\
\text { sayısı }\end{array}$ \\
Toplam \\
\end{tabular}} & \multirow{2}{*}{$\begin{array}{c}\text { Likert } \\
\text { ölçeği } \\
\text { Ortalama } \\
\end{array}$} \\
\hline & Say & / Oran & Say & / Oran & Say & / Oran & Sayı & / Oran & Sayı & Oran & & \\
\hline & 3 & 14.3 & & 4.8 & & & 1 & 4.8 & 16 & 79.2 & 21 & 4.24 \\
\hline $\begin{array}{l}\text { Çöp-katı atık tesis } \\
\text { yetersizliği }\end{array}$ & 6 & 28.6 & 2 & 9.5 & 1 & 4.8 & & - & 12 & 57.1 & 21 & 3.48 \\
\hline $\begin{array}{l}\text { Arıtma tesislerinin } \\
\text { bulunmaması }\end{array}$ & 3 & 14.3 & 3 & 14.3 & & & 1 & 4.8 & 14 & 66.7 & 21 & 3.95 \\
\hline $\begin{array}{l}\text { Hayvan atık ve } \\
\text { gübrelerinin sulara } \\
\text { bırakılması }\end{array}$ & 2 & 9.5 & 2 & 9.5 & 1 & 4.8 & 3 & 14.3 & 13 & 61.9 & 21 & 4.10 \\
\hline
\end{tabular}

Kentlerin sanayileşmeye dayalı olarak nüfusunun hızla artmasından kaynaklanan kentsel katı atık miktarı her geçen gün artmaktadır (Sedef 2016).

Atık çeşitleri evsel nitelikli ve endüstriyel nitelikli atıklar olarak sınıflandırılabilir. Günlük oluşan evsel nitelikli katı atıkların toplanması vahşi depolama yöntemi olan sağlıklı olmayan yöntemlerle gerçekleştirilmekte ve ilkel ortamlarda bertaraf edilmektedir. Bundan dolayı da katı atık yönetimi, planlaması, şehircilik ve finans konularında sorunlar yaşanmaktadır (Demircan, 2016).

Yapılan bir araştırmadaki tanımlayıcı istatistiksel bulgularında, katılımcıları çevre sorunları açısından en çok endişelendiren durumun küresel ısınma olduğu, onu nüfus artış hızı, temiz su kaynaklarının azalması ve buzulların erimesi takip etmektedir (Tatar, 2021).

\section{SONUÇ}

Sanayi işletmecilerinde ankete katılan erkeklerin oranı yaklaşık \%89.1, kadınların oranı ise \%10.9 gibi düşük bir orandadır. İşletmecilerin \%42.3 oranında 26-40 arası yaşa sahip oldukları görülmüştür. Evlilik oranları \%54.5 civarındadır. Eğitim seviyelerinin oldukça iyi olduğu ve çağın gerektirdiği iletişim kanallarını kullandıkları görülmüştür.

Ortalama hane halkı sayıları erkeklerde 2.3 kadınlarda ise 1.4 kişiyi geçmemekte, çok az miktarda kadın, işletme sahibi veya yönetici konumundadır. İşletmeler genellikle limited şirket olarak yapılandırılmışlar ve ortakları çoğunlukla aile fertlerinden oluşmaktadır. Köklü ve geleneksel işletmeler bulunmakla birlikte sanayi işletmecilerinin ortalama 10-15 yıllık deneyime sahip oldukları belirlenmiştir. Ticari işletmeler ise \%43.6 oranla öne çıkmaktadır. Sanayi işletmecilerinin bölgede en büyük çevre sorunu olarak algıladıkları durumların başında evsel atık ve fosseptik sorunu gelmektedir. Buna göre kesinlikle katılıyorum cevabı verenlerin oranının \%76.3 ile en fazla olduğu evsel atık ve fosseptik sorunu en büyük sorun olarak görülmekte iken, likert ölçeğine göre de en yüksek ortalama evsel atık ve fosseptik sorunudur (4.26).

Tokat ili sanayi işletmecilerinin çevre sorunlarına yönelik algısı incelendiğinde oransal olarak \%56.5 kesinlikle katılıyorum cevabıyla hava kirliliği sorunu en başta iken, likert ölçeğine göre de en yüksek ortalama hava kirliliği sorununda gözükmektedir (3.39).

Raporda atıkların 1. öncelikli sorun olduğu iller kapsamında olan ilde, sanayi işletmecilerinin algısı olan hava kirliliği sorunu raporla örtüşmemektedir.

Samsun ili sanayi işletmecilerinin çevre sorunlarına yönelik algısında oransal olarak kesinlikle katılıyorum cevabıyla ve \%91.8 oranla çöp- katı atık kirliliği sorunu ile evsel atık ve fosseptik sorunu başta gelirken çöp-katı atık kirliliği sorunu likert'e göre de 4.73 'tür.

Rapora göre atıkların 3. öncelikli sorun olduğu iller içerisinde olan evsel atıklar ve fosseptik sorunu noktasında sanayi işletmecilerinin algısı öne geçmektedir.

Çorum ili sanayi işletmecilerinin çevre sorunlarına yönelik algısı incelendiğinde oransal olarak kesinlikle katılıyorum cevabıyla ve \%92.5 oranla evsel atık ve fosseptik sorunu başta gelirken, likert ölçeğine göre de en yüksek ortalama evsel atık ve fosseptik sorununda gözükmektedir (4.75).

Amasya ili sanayi işletmecilerinin çevre sorunlarına yönelik algısında oransal olarak kesinlikle katılıyorum cevabıyla ve \%95.2 oranla evsel atık ve fosseptik sorunu başta gelirken, likert ölçeğine göre ise en yüksek ortalama evsel atık ve fosseptik sorununda gözükmektedir (4.86).

Sanayi işletmecilerinin bölgede en büyük çevre sorunu nedeni olarak algıladıkları durumların başında çarpık kentleşme gelirken, arıtma tesislerinin bulunmaması onu takip etmektedir. Nüfus artışı ve çöp-katı atık tesis 
yetersizliği az da olsa önemsenmektedir. Bölge genelinde sanayi işletmecileri tarafından çevre sorunlarının nedenlerine ilişkin sorulan sorulara verilen cevaplara göre, kesinlikle katılıyorum cevabı verenlerin oranını en fazla \%79.5 ile çarpık kentleşme iken, likert ölçeğine göre de neden olarak 4.38 ortalamayla en fazla oran çarpık kentleşmededir.

Tokat ili sanayi işletmecilerinin çevre sorunlarının nedenlerine yönelik algısı çarpık kentleşme ve nüfus artışı şeklindedir. Oransal bakıldığında ise \%80.4 kesinlikle katılıyorum cevabıyla nüfus artışı başta gelen nedendir.

Samsun ilinde ise çarpık kentleşme, nüfus artışı ve arıtma tesislerinin bulunmaması ve çöp-katı atık tesis yetersizliği en büyük nedenler olarak algılanmaktadır. Oransal bakıldığında ise \%91.8 ile ve kesinlikle katılıyorum cevabıyla çarpık kentleşme başta gelen nedendir.

Çorum ili sanayi işletmecilerinin çevre sorunlarının nedenlerine yönelik algısı da nüfus artışı, çarpık kentleşme ve arıtma tesislerinin bulunmaması şeklindedir. Oransal olarak bakıldığında ise \%85 ile ve kesinlikle katılıyorum cevabıyla nüfus artışı başta gelmektedir.

Amasya ili sanayi işletmecilerinin çevre sorunlarının nedenlerine yönelik algısı incelendiğinde çarpık kentleşme, hayvan atık ve gübrelerinin sulara bırakılması ve arıtma tesislerinin bulunmaması en büyük nedenler olarak algılanmaktadır. Oransal bakıldığında ise \%76.2 ile ve kesinlikle katılıyorum cevabıyla çarpık kentleşme başta gelen nedendir.

Daha temiz bir çevre için sanayi işletmecileri çevre konusunda bilinçlendirilmelidir. Çevre duyarlıı̆ııın artıııması için de sanayi ile ilgili kurumsal yapılar tarafından sanayi işletmecilerine sürekli eğitimler verilmeli ve farkındalıkları artırımalıdır.

\section{ÇIKAR ÇATIŞMASI}

Yazarlar arasında herhangi bir çıkar çatışması bulunmamaktadır.

\section{YAZAR KATKISI}

Makalenin konu dizaynı, yöntem, yazımı, istatistiksel analiz ve yorumları H.G. tarafından yapılmıştır. Yönlendirme, kontrol ve düzeltmeler H.K tarafından yapılmıştır.

\section{KAYNAKLAR}

Alsmadi, S. (2007). Green marketing and the concern over the environment: measuring environmental consciousness of jordanian consumers. Journal of Promotion Management, 13(3), 339-361.

Anonim. (2006). Dünya üzerinde çevre kirliliğinin en fazla olduğu 10 yer. http://www.hurriyet.com.tr/dunya/dunyada-cevrekirliliginin-enfazla-oldugu- 10-yer-5284840-. Erişim tarihi: 13 Eylül 2018.

Anonim. (2015a). Ekonomik İşbirliği ve Kalkınma Örgütü (OECD) 2015 çevre raporu (atık üretimi) https://www.haberler.com/oecd-cevre-raporu-7819771 Erişim tarihi: 30 Ocak 2019.

Anonim. (2017a). Çevre kirliliğinin etkileri. https://www.ensonhaber.com/cevre-kirliliginin-etkileri.html-Erişim tarihi: 05 Ocak 2019.

Anonim. (2017b). Why Varanasi's been ranked the most polluted city in India. Why varanasi's been ranked the most polluted city in Indiapicture of mridu rai 20idu rai updated: 14 November 2017polluted-city-in-india/-. Erişim tarihi: 14 Şubat 2019.

Anonim. (2018a). Dünya Çevre Günü Türkiye Raporu. TMMOB Çevre Mühendisleri Odası, Ankara.

Anonim. (2018b). The united nations world water development report. https://reliefweb.int/sites/reliefweb.int/files/resources/261424e.pdf. Erişim tarihi: 27 Ocak 2019.

Anonim. (2018c). Sürekli ve etkin çevre denetim sistemi. https:// www.ogm.gov.tr/ekutuphane- Erişim tarihi: 11 Aralık 2019.

Anonim. (2018d). Türkiye Çevre Sorunları ve Öncelikleri Değerlendirme Raporu, 2016 Yılı Verileriyle. Yayın No: 40, Ankara.

Anonim. (2019a). Amerika Birleşik Devletleri'ndeki su kirliliği hakkında alarm veren gerçekler. http://all-about-waterfilters.com/water-pollution-in-the-united-states-facts/.- Erişim tarihi: 21 Haziran 2019.

Anonim. (2019b). Sanayi kenti Kocaeli'nin artan cazibesi nüfusa da yansıdı. https://www.aa.com.tr/tr/ekonomi/sanayi-kentininartan-cazibesi-nufusa-da-yansidi/1558439- Erişim tarihi: 14 Nisan 2021.

Aydın, A. H., \& Çamur, Ö. (2016). Avrupa birliği çevre politikaları ve çevre eylem programları üzerine bir inceleme. http://busbed.bingol.edu.tr/download/article-file/299770-. Erişim tarihi: 24 Ocak 2019. 
Aydın, S. \&Tufan, F. (2018). Sürdürülebilirlik ve yeşil kavramları bağlamında y kuşağının satın alma davranışları. Selçuk Üniversitesi Illetişim Fakültesi Akademik Dergisi, 11(2), 397-420.

Ceyhan, S. (2018). Çevreye duyarlı işletmecilik Kahramanmaraş ilinde bir alan araştırması. Yüksek Lisans Tezi, Kahramanmaraş Sütçü İmam Üniversitesi. Sosyal Bilimler Enstitüsü, İşletme Ana Bilim Dalı, Kahramanmaraş.

Clark, G. (2007). Evolution of the global sustainable consumption and production policy and the united nations environment programme's supporting activities. Journal of Cleaner Production. (15), 492-498.

Coşkun, A. (2019). Tüketicilerin çevre bilinci ve çevreci tüketici satın alma davranışının incelenmesi. Yüksek Lisans Tezi, Afyon Kocatepe Üniversitesi Sosyal Bilimler Enstitüsü, Afyonkarahisar.

Çağlar, B. (2017). Küresel çevre sorunları. https://xyazar.com/kuresel-cevre-sorunlari. Erişim tarihi: 11 Ocak 2019.

Çetin, M., \& Kara, M. (2008). Bir kalkınma aracı olarak "organize sanayi bölgeleri": Isparta Süleyman Demirel organize sanayi bölgesi üzerine bir araştırma. Erciyes Üniversitesi Iktisadi ve Idari Bilimler Fakültesi Dergisi, 0(31), 49-68.

Çiçek, A., \& Erkan, O. (1996). Tarım Ekonomisinde Araştırma ve Örnekleme Yöntemleri. Tokat Gaziosmanpaşa Üniversitesi, Ziraat Fakültesi Yayınları, Ders Notları, Yayın No: 12.

Demircan, B. (2016). Van büyükşehir belediyesi entegre atık yönetimi planı oluşturulması. Yüksek Lisans Tezi, Harran Üniversitesi, Fen Bilimleri Enstitüsü, Şanlıurfa.

Dede, O. (2010). Trakya bölgesinde yaşanan çevre sorunları ve sosyo-ekonomik etkilerinin analizi. Doktora Tezi, Namık Kemal Üniversitesi. Fen Bilimleri Enstitüsü, Tarım Ekonomisi Anabilim Dalı, Tekirdağ.

Dura, C. (2012). Çevre sorunları ve ekonomi. http://www.cihandura.com/tr/makale/ Erişim tarihi: 11 Ekim 2018.

Ergün, A., 2008. Sivas şehrinde kentleşme ve sanayileşmeye bağlı çevre sorunları. Yüksek Lisans Tezi, Selçuk Üniversitesi. Sosyal Bilimler Enstitüsü, Konya.

Fındık, M. S. (2007). Türkiye'de çevre kirliliğine yol açan unsurların önlenmesi çerçevesinde yeşil vergi. Yüksek Lisans Tezi, Marmara Üniversitesi, Sosyal Bilimler Enstitüsü, İstanbul.

Görmez, K. (2015). Çevre Sorunları. Nobel Akademik Yayıncılık, Ankara.

İbeji, G \& Chikaire, J. U. (2016). Chikaire federal university of technology, owerri, ımo state, nigeria consequences of environmental pollution on agricultural productivity in developing countries: a case of nigeria. International Journal of Agricultural and Food Research, 5(3), 1-12.

Kaypak, Ş. (2010). Kent ve Çevre Sorunları. Basılı Ders Notları. Hatay Mustafa Kemal Üniversitesi, Antakya.

Kaypak, Ş. (2012). Çevre hukukunun ulusal ve uluslararası boyutları. Adıyaman Üniversitesi Sosyal Bilimler Enstitüsü Dergisi, 10, 206.

Kızılaslan N., \& Kızılaslan H. (2009). Environment sensitivity of the families that ımmigrated from rural to the urban areas. Journal of Food, Agriculture \& Environment, 2(7), 788-792.

Özocaklı, D. (2009). Imalat işletmelerinde çevre duyarlıı̆̆ı. Yüksek Lisans Tezi, Gaziantep Üniversitesi, Sosyal Bilimler Enstitüsü İşletme Ana Bilim Dalı, Gaziantep.

Sancar, P. (2007). Türkiye'de çevre koruma ve ekonomik büyüme ilişkisi. Yüksek Lisans Tezi, Trakya Üniversitesi, Sosyal Bilimler Enstitüsü, Edirne.

Sedef, M. (2016). Katı atık yönetimi. Uzmanlık Tezi, İller Bankası Anonim Şirketi, 114, Ankara.

Tatar, A. (2021). Çevresel sorunlara duyarlıığının sürdürülebilir tüketim davranışına etkisi. International Journal of Management and Administration, 5(9), 113-114.

Yücel, M, \& Ekmekçiler, Ü., S. (2008). Çevre dostu ürün kavramına bütünsel yaklaşım: temiz üretim sistemi, eko etiket, yeşil pazarlama. Elektronik Sosyal Bilimler Dergisi, 7, 320-333. 